\title{
Review Article \\ The Possible Role of Vitamin D Deficiency in Early Implant Failure
}

\author{
Lotfollah Kamali Hakim $\mathbb{D}^{1},{ }^{1}$ Tayebeh Ghasemi, ${ }^{2}$ Saeed Bashar $\mathbb{D}{ }^{3}$ and Dorara Dortaj $\mathbb{D}^{4}$ \\ ${ }^{1}$ Department of Oral \& Maxillofacial Surgery, School of Dentistry, Tehran University of Medical Sciences, Tehran, Iran \\ ${ }^{2}$ Department of Oral and Maxillofacial Surgery, School of Dentistry, Zahedan University of Medical Sciences, Zahedan, Iran \\ ${ }^{3}$ Department of Oral and Maxillofacial Surgery, Faculty of Dentistry, Golestan University of Medical Sciences, Gorgan, Iran \\ ${ }^{4}$ Department of Operative Dentistry, School of Dentistry, Tehran University of Medical Sciences, Tehran, Iran
}

Correspondence should be addressed to Saeed Bashar; basharsaeed61@gmail.com

Received 28 December 2020; Revised 2 March 2021; Accepted 22 March 2021; Published 7 April 2021

Academic Editor: Verica Pavlic

Copyright @ 2021 Lotfollah Kamali Hakim et al. This is an open access article distributed under the Creative Commons Attribution License, which permits unrestricted use, distribution, and reproduction in any medium, provided the original work is properly cited.

Background. Dental implants are one of the most successful treatments for restoring tooth function and beauty. Identifying the causes of dental implant failure is useful and vital. This review was aimed at studying the possible role of vitamin D in early implant failure. Method and Material. This review was designed based on the PRISMA guideline. Data was collected using keywords including implant, vitamin D, deficiency, failure, dental, OR tooth in international databases including PubMed, Scopus, Web of Science, Cochrane, and Embase, until 2020. Based on the inclusion and exclusion criteria, data were extracted and gathered in a checklist. Results. Finally, twelve studies were selected from five different countries. In 6 studies (2 animal studies and four human studies), there was no significant relationship between vitamin D deficiency and dental implant failure. In the other six studies (1 animal study and five human studies), there was a significant relationship in this regard. Conclusion. It is difficult to conclude the association between vitamin D and implant failure based on the literature's researches. However, vitamin D appears to play an essential role in implant success through its effects on immune system modulation.

\section{Introduction}

Tooth decay is one of the main problems in aged people worldwide [1]. It can affect their chewing and tooth function and, as a result, the quality of their lives $[2,3]$. Depending on the patient's clinical condition and needs, dentists use conventional tooth-supported, implant-supported, or combined tooth implant-supported prosthetic [4]. The implantsupported dental prosthesis is now widely used to replace one or more missing teeth [4]. Currently, dental implants are among the most successful treatments for restoring tooth function and beauty $[5,6]$.

Osseointegration helps create a direct interface between the implant and the bone, an essential element for successful dental implant procedures. During the initial recovery period, it is crucial to (1) insert the implant into the bone correctly and (2) maintain the implant in its position over time [7-9]. The amount of bone accumulation in dental implants depends on several factors, including surgical and prosthetic factors (surgical technique and experience of the surgeon, timing and type of prosthesis, and also its quality), implantrelated factors (materials, design, and surface), and patientrelated factors (bone volume, the quality of the bone, and the host's response) [10-12].

Dental implant failure usually refers to implant failure to osseointegrate accurately with the bone, or vice versa, also when it is lost and mobile or indicates peri-implant bone loss of more than $1 \mathrm{~mm}$ in the first year and more than $0.2 \mathrm{~mm}$ in the second year [13]. Based on time criteria, failures can be classified as Early Dental Implant Failures (EDIFs) and Late Dental Implant Failures (LDIFs). EDIFs are due to unsuccessful reabsorption representing impairment in the bone repair, while LDIFs are due to loss of osseointegration [14, 15]. Factors causing EDIFs include diabetes, tobacco use, history of periodontitis, length and diameter of the implant, foreign body reaction, and localized bone necrosis due to heat production during bone preparation or implant replacement $[15,16]$. 
Given that DIFs occur in a specific group of patients, this may be related to the patient's systemic health $[17,18]$. Therefore, identifying systemic risk factors may lead to a reduction in these failures. Some of these factors, especially vitamin $\mathrm{D}$ deficiency, can play an essential role in the development of EDIFs $[14,15,18]$.

Vitamin D (vitamin D3 or cholecalciferol) is a steroid hormone that can be consumed orally or, to some extent, be made from cholesterol in the skin by exposure to sunlight (UV light) [19]. Cholesterol is converted to previtamin D3 and isomerized to vitamin D3, and then, after binding to its binding protein, it will be transported to the liver where hydroxylated CYP27A1 enzyme catalyzes its conversion to 25-hydroxy vitamin D3 [19]. Serum level of $25(\mathrm{OH}) \mathrm{D}$ or 25 -hydroxyvitamin $\mathrm{D}$ less than $10 \mathrm{ng} / \mathrm{ml}$ is considered severe deficiency; $24-10 \mathrm{ng} / \mathrm{ml}$, deficiency; and 25-80 ng/ml, normal [20].

Since dental protein rearrangement is determined by bone metabolism, low levels of vitamin $\mathrm{D}$ can negatively impact the process of repair and new bone formation on the implant surface [21]. Low vitamin D levels are associated with an increased risk of peripheral joint infections [22]. In rodents, vitamin D causes bone formation around the implant. Several studies reported the association between vitamin D deficiency and DIFs in animal models [23, 24]. Some researchers examined the relationship between bone metabolism, vitamin $\mathrm{D}$, and early implant failure in humans, but the reported association is still controversial [25-27]; therefore, a comprehensive study in this field seems necessary. The present study was aimed at evaluating the association between vitamin $\mathrm{D}$ and EDIFs.

\section{Method and Material}

2.1. Study Design. The present review was designed based on the PRISMA guideline [28].

2.2. Search Strategy. Data was collected using keywords including vitamin $\mathrm{D}$, vitamin $\mathrm{D}$ deficiency, dental implants, and implant failure in international databases including PubMed, Scopus, Web of Science, Cochrane, and Embase, until 1 February 2020. All the references were checked manually. For the PubMed database, this syntax was used: ("vitamin d deficiency" [MeSH] OR "vitamin D deficiency"[TIAB] OR “Vitamin D"[Mesh] OR “Vitamin D”[TIAB]) AND ("Dental Implants"[MeSH] OR "Dental Implants"[TIAB] OR “implant failure"[TIAB]).

2.3. Inclusion Criteria. First, the title and then the abstracts were independently reviewed by two authors (LHK and $\mathrm{SB})$. Studies investigating the effect of vitamin D deficiency on dental implants and the failure of dental implants due to vitamin $\mathrm{D}$ deficiency in humans and animals were included in this study. The success of dental implants is commonly defined by implant survival. Serum level of $25(\mathrm{OH}) \mathrm{D}$ or 25 -hydroxyvitamin $\mathrm{D}$ less than $10 \mathrm{ng} / \mathrm{ml}$ is considered severe deficiency; $24-10 \mathrm{ng} / \mathrm{ml}$, deficiency; and $25-80 \mathrm{ng} / \mathrm{ml}$, normal [20].
2.4. Exclusion Criteria. The exclusion criteria consisted of topic irrelevance, duplicate, or incomplete data. Review articles were excluded from the study.

2.5. Data Extraction. Data were extracted by year, location, the purpose of study, method of study, and results. Information was categorized by authors' name, year of publication, study location and type of study, and the number, age, and sex of patients.

\section{Result}

In the initial search, 1200 articles were found. After eliminating unrelated, duplicate, and incomplete information, twelve studies were finally entered in this study. The steps for selecting studies are given in Figure 1.

Tables 1 and 2 provide information on the 12 main studies, including the author's name, year of publication, location, sample size, method, and study results. These studies were selected from five different countries (Italy, Brazil, Spain, United States, Korea, and Germany). The highest number of studies was in Brazil, with four studies. This review included nine human studies in Table 1 and 3 animal studies in Table 2. In 6 studies (2 animal studies and four human studies), there was no significant relationship between vitamin $\mathrm{D}$ deficiency and dental implant failure. In the other six studies ( 1 animal study and five human studies), there was a significant relationship in this regard. The study quality was also checked, and low possibility of bias was reported for them.

In a review study of Tabanella, the author concluded that the numbers of osteoclasts formed and their resorption activity is enhanced by the addition of 1.25-(OH)2D3 [29]. In Insua et al.'s study, osteocytes and immune cells' influence was key regulators during dental implant osseointegration and maintenance [9].

\section{Discussion}

This review was aimed at studying the possible role of vitamin D in DIFs. In the present review, twelve original articles were studied. Despite the high success rate of dental implants, implant failure has been reported in some cases. Baqain et al. in Oman studied 169 patients with a total of 399 implants. They found that fifteen implants in 14 patients (8\%) were unsuccessful [30]. In a study by Jafarian et al. in Iran, out of 1533 dental implants in 250 patients, 61 (4\%) failed [31]. They observed that the maxilla had the highest fracture rate (9 out of 132 implants (6.8\%)) [31]. There are several reasons for failure in dental implants, including vitamin $\mathrm{D}$ deficiency. There are also several studies indicating the high prevalence of vitamin D deficiency worldwide [32-34]. Vitamin D deficiency is a global health problem for all age groups, especially in the Middle East [35]. Due to the increasing prevalence of vitamin $\mathrm{D}$ deficiency worldwide, dental implant failure rates may increase over time. In the investigated researches, a remarkable variation in the studied populations was apparent. Mangano et al. reported the largest sample sizes with 885 samples. 

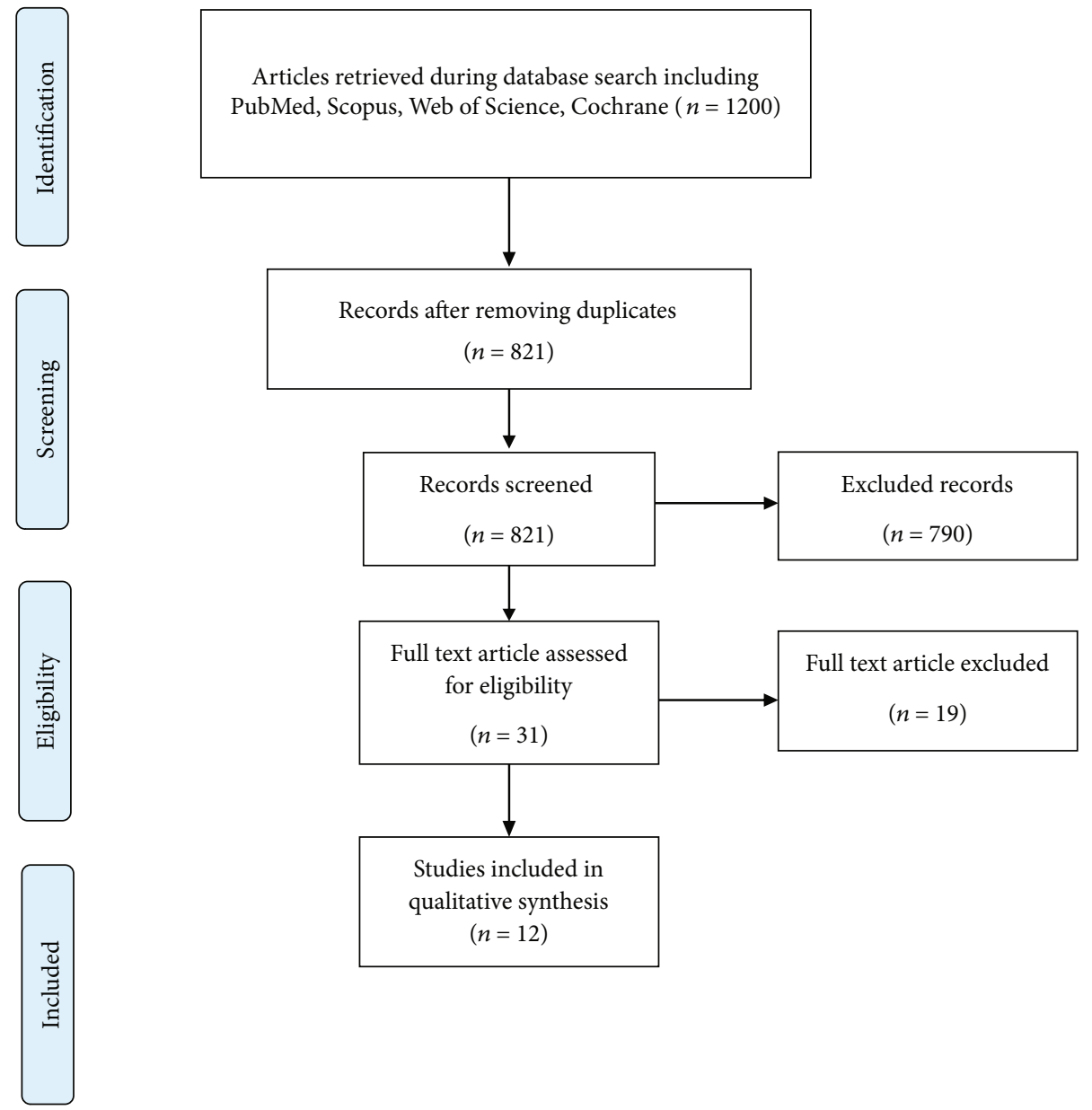

Figure 1: Flowchart describing the study design process.

On the other hand, Bryce and MacBeth's studies were conducted just by one sample involved $[26,36]$. Twentyfive percent of these studies used animal models, including dogs and rabbits. Human studies were performed as a randomized controlled trial, case control, and case report. These variations will make it difficult to make a solid conclusion on the subject. The most reliable studies after systematic review and meta-analysis are the RSTs. These types of studies can guide scientists accurately to resolve scientific gaps. However, case report studies in case of lacking good sample size can help the researchers. Cross-sectional studies are performed to study deceptive aspects of a population in a specific time but cannot determine the relation or cause of something.

Six of the investigated studies found a significant association between vitamin D deficiency and DIFs, but there was no significant relationship between these two criteria in the other six studies. Our results showed few pieces of evidence of the association between vitamin D levels and the success rate in dental implantation. Because of the contradictory results obtained from those studies, it is recommended to conduct comprehensive studies with larger sample sizes.

The role of vitamin $\mathrm{D}$ in the calcium economy is extremely important. During osteointegration, calcitriol affects the processes of activation and differentiation of osteoblasts and osteoclasts. Vitamin D has also been found to be essential for the maturation and proper functioning of bone cells by the production of a factor stimulating osteoclast precursor fusion and stimulation of osteoblast differentiation. Vitamin D also increases osteoid mineralization [37]. Also, this mechanism can play an important role in the stabilization phase of the implant, after stabilization is achieved by loading it with a prosthetic crown.

In addition to its role in calcium and bone homeostasis, vitamin $D$ plays a vital role in modulating the innate and adaptive immune responses [38]. Recent studies suggest that vitamin $\mathrm{D}$, as an essential immune response regulator, mostly targets innate immune response because all immune cells express the vitamin D receptor (VDR) response [39, 40]. Changes in cytokine secretion due to vitamin $\mathrm{D}$ deficiency can impair osteoclast activation and differentiation through VDR activation [41]. It is hypothesized that metallic particles affect macrophages and lymphocytes to release inflammatory cytokines, leading to increased osteoclastogenesis and decreased osteoblastogenesis, which eventually results in peri-implant bone degeneration [42]. Vitamin D may also be essential for the antibacterial response because it affects the monocyte-macrophages [43]. Xu et al. showed that vitamin $\mathrm{D}$ could inhibit gingivalis-induced proinflammatory cytokine expression and, at the same time, improves the expression of anti-inflammatory cytokines in macrophages [44]. 
TABLE 1: Clinical studies about the relation between vitamin D and early implant failure.

\begin{tabular}{|c|c|c|c|c|c|c|c|c|}
\hline $\begin{array}{l}\text { Author } \\
\text { name }\end{array}$ & Country & $\begin{array}{c}\text { Sample } \\
\text { size }\end{array}$ & $\begin{array}{c}\text { Ge } \\
\text { Male }\end{array}$ & $\begin{array}{l}\text { ender } \\
\text { Female }\end{array}$ & Method & Result & Conclusion & Reference \\
\hline $\begin{array}{l}\text { Mangano } \\
\text { et al., } 2018\end{array}$ & Italy & $\begin{array}{c}885 \\
\text { humans }\end{array}$ & 455 & 430 & $\begin{array}{l}\text { Cross- } \\
\text { sectional }\end{array}$ & $\begin{array}{c}\text { No significant relationship } \\
\text { was found between implant } \\
\text { failure and vitamin D } \\
\text { deficiency }\end{array}$ & $\begin{array}{c}\text { A dramatic increase in EDIFs } \\
\text { with the lowering of vitamin D } \\
\text { levels in the blood has been } \\
\text { reported }\end{array}$ & {$[36]$} \\
\hline $\begin{array}{l}\text { Mangano } \\
\text { et al., } 2016\end{array}$ & Italy & $\begin{array}{c}822 \\
\text { humans }\end{array}$ & 429 & 398 & $\begin{array}{l}\text { Cross- } \\
\text { sectional }\end{array}$ & $\begin{array}{c}\text { No significant relationship } \\
\text { was found between implant } \\
\text { failure and vitamin D } \\
\text { deficiency }\end{array}$ & $\begin{array}{l}\text { Vitamin D deficiency has no } \\
\text { impact on implant failure }\end{array}$ & {$[45]$} \\
\hline $\begin{array}{l}\text { Fretwurst } \\
\text { et al., } 2016\end{array}$ & $\begin{array}{l}\text { Germany } \\
\text { (Freburg) }\end{array}$ & $\begin{array}{c}2 \\
\text { humans }\end{array}$ & 2 & - & Case report & $\begin{array}{c}\text { Implant placement was } \\
\text { successful after vitamin } \mathrm{D} \\
\text { supplementation in patients } \\
\text { with vitamin D deficiency and } \\
\text { early failed implants }\end{array}$ & $\begin{array}{l}\text { Standard screening of vitamin } \\
\mathrm{D} \text { in dental implantology may } \\
\text { be helpful given the evidence }\end{array}$ & {$[46]$} \\
\hline $\begin{array}{l}\text { Boas et al., } \\
2019\end{array}$ & Brazil & $\begin{array}{c}10 \\
\text { humans }\end{array}$ & - & - & Case control & $\begin{array}{l}\text { Despite altered serum levels of } \\
\text { vitamin } \mathrm{D} \text {, there is no clinical } \\
\text { correlation with } \\
\text { osseointegration deficiency } \\
\text { and bone remodeling system }\end{array}$ & $\begin{array}{l}\text { Vitamin D insufficiency is not } \\
\text { a real contraindication for } \\
\text { implant placement }\end{array}$ & {$[8]$} \\
\hline $\begin{array}{l}\text { Vedururu } \\
\text { et al., } 2016\end{array}$ & $\begin{array}{l}\text { United } \\
\text { States } \\
\text { (Buffalo) }\end{array}$ & $\begin{array}{c}362 \\
\text { humans }\end{array}$ & - & - & $\begin{array}{l}\text { Cross- } \\
\text { sectional }\end{array}$ & $\begin{array}{l}\text { Sixty-three }(30 \%) \text { patients had } \\
\text { intake supplemented with } \\
\text { vitamin D and } 5(1.3 \%) \\
\text { failures were reported. The } \\
\text { number of failures in patients } \\
\text { who are not taking vitamin D } \\
\text { supplementation is } 10(2.7 \%)\end{array}$ & $\begin{array}{c}\text { The data suggest that vitamin } \\
\mathrm{D} \text { intake may minimize dental } \\
\text { implant loss }\end{array}$ & \\
\hline $\begin{array}{l}\text { Bryce and } \\
\text { MacBeth, } \\
2014\end{array}$ & England & $\begin{array}{c}1 \\
\text { human }\end{array}$ & 1 & - & Case report & $\begin{array}{l}\text { Five months postoperatively, } \\
\text { no osseointegration of the } \\
\text { implant was found. The } \\
\text { patient was severely vitamin D } \\
\text { deficient, and this may have } \\
\text { contributed to the implant } \\
\text { failure }\end{array}$ & $\begin{array}{l}\text { Vitamin D deficiency may } \\
\text { play a role in the failure of } \\
\text { osseointegration in dental } \\
\text { implants }\end{array}$ & {$[26]$} \\
\hline $\begin{array}{l}\text { Pereira } \\
\text { et al., } 2019\end{array}$ & Brazil & $\begin{array}{c}244 \\
\text { humans }\end{array}$ & 82 & 162 & Case-control & $\begin{array}{l}\text { The allele G of rs } 3782905 \text { in } \\
\text { the recessive model, together } \\
\text { with the number of installed } \\
\text { implants and gingival index, } \\
\text { was significantly associated } \\
\text { with implant failure }\end{array}$ & $\begin{array}{l}\text { It is suggested that the allele } \mathrm{G} \\
\text { of rs } 3782905 \text { in the recessive } \\
\text { model may be a new genetic } \\
\text { risk marker for dental implant } \\
\text { loss }\end{array}$ & {$[47]$} \\
\hline $\begin{array}{l}\text { Alvim- } \\
\text { Pereira } \\
\text { et al., } 2008\end{array}$ & Brazil & $\begin{array}{c}207 \\
\text { humans }\end{array}$ & 50 & 87 & Case-control & $\begin{array}{l}\text { No association between } \\
\text { genotypes or alleles of VDR } \\
\text { TaqI polymorphism and } \\
\text { implant loss was found }\end{array}$ & $\begin{array}{l}\text { More studies considering } \\
\text { other polymorphic regions of } \\
\text { the VDR gene might be } \\
\text { performed to clarify its } \\
\text { importance in implant loss } \\
\text { physiopathology }\end{array}$ & {$[25]$} \\
\hline $\begin{array}{l}\text { Schulze- } \\
\text { Späte } \\
\text { et al., } 2016\end{array}$ & $\begin{array}{l}\text { United } \\
\text { States }\end{array}$ & $\begin{array}{l}20 \\
\text { humans }\end{array}$ & 13 & 7 & $\begin{array}{l}\text { Randomized, } \\
\text { double-blind, } \\
\text { placebo- } \\
\text { controlled } \\
\text { trial }\end{array}$ & $\begin{array}{l}\text { No significant difference in } \\
\text { bone formation or graft } \\
\text { resorption was detected } \\
\text { between groups. However, in } \\
\text { the vitamin D3 group, a } \\
\text { significant association was } \\
\text { found between increased } \\
\text { vitamin D levels and a number } \\
\text { of bone-resorbing osteoclasts } \\
\text { around graft particles }\end{array}$ & $\begin{array}{l}\text { Vitamin D3+ calcium } \\
\text { supplementation improves } \\
\text { serum vitamin D levels and } \\
\text { potentially impacts local bone } \\
\text { remodeling on a cellular level }\end{array}$ & {$[48]$} \\
\hline
\end{tabular}


TABLe 2: Animal studies about the relation between vitamin D and early implant failure.

\begin{tabular}{|c|c|c|c|c|c|}
\hline $\begin{array}{l}\text { Author } \\
\text { name }\end{array}$ & Country & $\begin{array}{c}\text { Sample } \\
\text { size }\end{array}$ & Result & Conclusion & Reference \\
\hline $\begin{array}{l}\text { Salomo- } \\
\text { Coll } \\
\text { et al., } \\
2015\end{array}$ & Spain & 24 dogs & $\begin{array}{l}\text { No statistically differences could be found between } \\
\text { the two groups }\end{array}$ & $\begin{array}{l}\text { With the limitation of animal studies, } \\
\text { topical application of vitamin D on dental } \\
\text { implants could reduce crestal bone loss } \\
\text { and increase } 10 \% \text { more bone-to-implant } \\
\text { contact at a } 12 \text {-week follow-up period }\end{array}$ & [49] \\
\hline $\begin{array}{l}\text { Naito } \\
\text { et al., } \\
2014\end{array}$ & Brazil & $\begin{array}{l}28 \\
\text { rabbits }\end{array}$ & $\begin{array}{l}\text { The } 1.25-(\mathrm{OH}) 2 \mathrm{D} 3 \text {-coated implants tended to } \\
\text { osseointegrate better than the noncoated surfaces. } \\
\text { The differences were not significant }\end{array}$ & $\begin{array}{c}\text { Future studies are recommended to } \\
\text { investigate a base substrate's development } \\
\text { that can maintain } 1.25-(\mathrm{OH}) 2 \mathrm{D} 3 \text { for a } \\
\text { long period }\end{array}$ & {$[24]$} \\
\hline $\begin{array}{l}\text { Cho } \\
\text { et al., } \\
2011\end{array}$ & Korea & $\begin{array}{l}12 \\
\text { rabbits }\end{array}$ & $\begin{array}{l}\text { A significant relationship was found between the case } \\
\text { and control groups }\end{array}$ & $\begin{array}{l}\text { This study demonstrated that the } \\
\text { PLGA/1 } \alpha, 25-(\mathrm{OH}) 2 \mathrm{D} 3 \text { solution coating } \\
\text { resulted in submicron-sized particles, } \\
\text { which may stimulate bone formation } \\
\text { adjacent to the surface of implants } \\
\text { inserted into bone }\end{array}$ & {$[50]$} \\
\hline
\end{tabular}

Vitamin D affects different stages of peri-implant bone formation. It has become an active factor in dental and implant surgery because of its effects on bone metabolism and the immune system. Given the high percentage of patients with vitamin $\mathrm{D}$ deficiency, it seems necessary to examine vitamin D deficiency before implant and dental surgery. It is recommended to conduct comprehensive studies with larger sample sizes to determine the exact mechanism involved. The limitations of the study include the limited number of clinical studies and small sample sizes. Our search shows that there are few clinical studies in this field; also, some of them contain a small sample size; this point should be resolved in future studies.

\section{Conclusion}

It is difficult to conclude the association between vitamin D and implant failure based on the current research in the literature. The studies' findings were inconsistent, but some of this research noted the effect of vitamin D on implant failure. Vitamin D may play a role in improving implant success through its effects on the immune system modulation. This hypothesis needs more clinical studies to be approved.

\section{Conflicts of Interest}

The authors declare that they have no conflicts of interest.

\section{References}

[1] N. J. Kassebaum, E. Bernabe, M. Dahiya, B. Bhandari, C. J. Murray, and W. Marcenes, "Global burden of severe tooth loss: a systematic review and meta-analysis," Journal of Dental Research, vol. 93, 7_suppl, pp. 20s-28S, 2014.

[2] D. G. Haag, K. G. Peres, M. Balasubramanian, and D. S. Brennan, "Oral conditions and health-related quality of life: a systematic review," Journal of Dental Research, vol. 96, no. 8, pp. 864-874, 2017.

[3] M. T. John, T. D. Koepsell, P. Hujoel, D. L. Miglioretti, L. LeResche, and W. Micheelis, "Demographic factors, denture status and oral health-related quality of life," Community Dentistry and Oral Epidemiology, vol. 32, no. 2, pp. 125-132, 2004.

[4] K. Dhingra, "Oral rehabilitation considerations for partially edentulous periodontal patients," Journal of Prosthodontics, vol. 21, no. 6, pp. 494-513, 2012.

[5] B. R. Chrcanovic, J. Kisch, T. Albrektsson, and A. Wennerberg, "A retrospective study on clinical and radiological outcomes of oral implants in patients followed up for a minimum of 20 years," Clinical Implant Dentistry and Related Research, vol. 20, no. 2, pp. 199-207, 2018.

[6] F. G. Mangano, P. Mastrangelo, F. Luongo, A. Blay, S. Tunchel, and C. Mangano, "Aesthetic outcome of immediately restored single implants placed in extraction sockets and healed sites of the anterior maxilla: a retrospective study on 103 patients with 3 years of follow-up," Clinical Oral Implants Research, vol. 28, no. 3, pp. 272-282, 2017.

[7] C. Mangano, F. Iaculli, A. Piattelli, and F. Mangano, "Fixed restorations supported by Morse-taper connection implants: a retrospective clinical study with 10-20 years of follow-up," Clinical Oral Implants Research, vol. 26, no. 10, pp. 12291236, 2015.

[8] R. Boas, C. Ramirez, A. Pinheiro et al., "Analysis of the effects of vitamin d insufficiency on osseointegration of dental implants," Clinical Oral Implants Research, vol. 30, no. S19, p. 113, 2019.

[9] A. Insua, A. Monje, H. L. Wang, and R. J. Miron, "Basis of bone metabolism around dental implants during osseointegration and peri-implant bone loss," Journal of Biomedical Materials Research Part A, vol. 105, no. 7, pp. 2075-2089, 2017.

[10] F. Suarez, H. L. Chan, A. Monje, P. Galindo-Moreno, and H. L. Wang, "Effect of the timing of restoration on implant marginal bone loss: a systematic review," Journal of Periodontology, vol. 84, no. 2, pp. 159-169, 2013.

[11] J. A. Shibli, J. T. Pires, A. Piattelli et al., "Impact of different implant surfaces topographies on peri-implant tissues: an update of current available data on dental implants retrieved from human jaws," Current Pharmaceutical Biotechnology, vol. 18, no. 1, pp. 76-84, 2017.

[12] S. Jawad, C. Barclay, W. Whittaker, M. Tickle, and T. Walsh, "A pilot randomised controlled trial evaluating mini and conventional implant retained dentures on the function and 
quality of life of patients with an edentulous mandible," $B M C$ Oral Health, vol. 17, no. 1, p. 53, 2017.

[13] P.-I. Bra-nemark, G. A. Zarb, T. Albrektsson, and H. M. Rosen, "Tissue-integrated prostheses. osseointegration in clinical dentistry," Plastic and Reconstructive Surgery, vol. 77, no. 3, pp. 496-497, 1986.

[14] G. Lin, S. Ye, F. Liu, and F. He, “A retrospective study of 30,959 implants: risk factors associated with early and late implant loss," Journal of Clinical Periodontology, vol. 45, no. 6, pp. 733-743, 2018.

[15] H. Mohajerani, R. Roozbayani, S. Taherian, and R. Tabrizi, "The risk factors in early failure of dental implants: a retrospective study," Journal of Dentistry, vol. 18, no. 4, pp. 298303, 2017.

[16] M. Borba, D. Deluiz, E. Lourenco, L. Oliveira, and P. Tannure, "Risk factors for implant failure: a retrospective study in an educational institution using GEE analyses," Brazilian Oral Research, vol. 31, article e69, 2017.

[17] T. Jemt, “A retro-prospective effectiveness study on 3448 implant operations at one referral clinic: a multifactorial analysis. Part I: clinical factors associated to early implant failures," Clinical Implant Dentistry and Related Research, vol. 19, no. 6, pp. 980-988, 2017.

[18] O. Buhara and S. Pehlivan, "Estimating the importance of significant risk factors for early dental implant failure: a Monte Carlo simulation," The International Journal of Oral \& Maxillofacial Implants, vol. 33, no. 1, pp. 161-168, 2018.

[19] J. E. Gunton and C. M. Girgis, "Vitamin D and muscle," Bone Reports, vol. 8, pp. 163-167, 2018.

[20] K. A. Kennel, M. T. Drake, and D. L. Hurley, "Vitamin D deficiency in adults: when to test and how to treat," Mayo Clinic Proceedings, vol. 85, no. 8, pp. 752-758, 2010.

[21] F. Javed, H. Malmstrom, S. V. Kellesarian, A. A. Al-Kheraif, F. Vohra, and G. E. Romanos, "Efficacy of vitamin D3 supplementation on osseointegration of implants," Implant Dentistry, vol. 25, no. 2, pp. 281-287, 2016.

[22] G. S. Maier, K. Horas, J. B. Seeger, K. E. Roth, A. A. Kurth, and U. Maus, "Is there an association between periprosthetic joint infection and low vitamin D levels?," International Orthopaedics, vol. 38, no. 7, pp. 1499-1504, 2014.

[23] G. Dvorak, A. Fugl, G. Watzek, S. Tangl, P. Pokorny, and R. Gruber, "Impact of dietary vitamin D on osseointegration in the ovariectomized rat," Clinical Oral Implants Research, vol. 23, no. 11, pp. 1308-1313, 2012.

[24] Y. Naito, R. Jimbo, M. S. Bryington et al., "The influence of $1 \alpha .25$-dihydroxyvitamin $\mathrm{d} 3$ coating on implant osseointegration in the rabbit tibia," Journal of Oral \& Maxillofacial Research, vol. 5, no. 3, p. e3, 2014.

[25] F. Alvim-Pereira, C. Montes, G. Thomé, M. Olandoski, and P. Trevilatto, "Analysis of association of clinical aspects and vitamin D receptor gene polymorphism with dental implant loss," Clinical Oral Implants Research, vol. 19, no. 8, pp. 786795, 2008.

[26] G. Bryce and N. MacBeth, "Vitamin D deficiency as a suspected causative factor in the failure of an immediately placed dental implant: a case report," Journal of the Royal Naval Medical Service, vol. 100, no. 3, pp. 328-332, 2014.

[27] J. Choukroun, G. Khoury, F. Khoury et al., "Two neglected biologic risk factors in bone grafting and implantology: high lowdensity lipoprotein cholesterol and low serum vitamin $\mathrm{D}$," The Journal of oral implantology., vol. 40, no. 1, pp. 110-114, 2014.
[28] A. C. Tricco, E. Lillie, W. Zarin et al., "PRISMA Extension for Scoping Reviews (PRISMA-ScR): checklist and explanation," Annals of Internal Medicine, vol. 169, no. 7, pp. 467-473, 2018.

[29] G. Tabanella, Ed., "May vitamin D intake be a risk factor for peri-implant bone loss? A critical review," EC Dental Science, vol. 15, no. 3, pp. 71-76, 2017.

[30] Z. Baqain, W. Moqbel, and F. Sawair, "Early dental implant failure: risk factors," The British Journal of Oral \& Maxillofacial Surgery., vol. 50, pp. 239-243, 2011.

[31] M. Jafarian, M. Bayat, A.-H. Pakravan, and N. Emadi, “Analysis of the factors affecting surgical success of implants placed in Iranian warfare victims," Medical Principles and Practice, vol. 25, no. 5, pp. 449-454, 2016.

[32] A. Mithal, D. A. Wahl, J. P. Bonjour et al., "Global vitamin D status and determinants of hypovitaminosis D," Osteoporosis International, vol. 20, no. 11, pp. 1807-1820, 2009.

[33] N. M. van Schoor and P. Lips, "Worldwide vitamin D status," Best Practice \& Research. Clinical Endocrinology \& Metabolism, vol. 25, no. 4, pp. 671-680, 2011.

[34] D. A. Wahl, C. Cooper, P. R. Ebeling et al., "A global representation of vitamin D status in healthy populations," Archives of Osteoporosis, vol. 7, no. 1-2, pp. 155-172, 2012.

[35] C. Palacios and L. Gonzalez, "Is vitamin D deficiency a major global public health problem?," The Journal of Steroid Biochemistry and Molecular Biology, vol. 144, Part A, pp. 138145, 2014.

[36] F. Guido Mangano and O. S. Ghertasi, "Low serum vitamin D and early dental implant failure: is there a connection? A retrospective clinical study on 1740 implants placed in 885 patients," Journal of Dental Research Dental Clinics Dental Prospects, vol. 12, no. 3, pp. 174-182, 2018.

[37] G. Trybek, M. Aniko-Wlodarczyk, J. Kwiatek et al., “The effect of vitamin D3 on the osteointegration of dental implant," Baltic Journal of Health and Physical Activity, vol. 10, no. 4, pp. 25-33, 2018.

[38] C. Aranow, "Vitamin D and the immune system," Journal of Investigative Medicine, vol. 59, no. 6, pp. 881-886, 2011.

[39] F. Baeke, T. Takiishi, H. Korf, C. Gysemans, and C. Mathieu, "Vitamin D: modulator of the immune system," Current Opinion in Pharmacology, vol. 10, no. 4, pp. 482-496, 2010.

[40] M. T. Cantorna, L. Snyder, Y. D. Lin, and L. Yang, "Vitamin D and 1, $25(\mathrm{OH}) 2 \mathrm{D}$ regulation of T cells," Nutrients, vol. 7, no. 4, pp. 3011-3021, 2015.

[41] C. L. Long and M. B. Humphrey, "Osteoimmunology: the expanding role of immunoreceptors in osteoclasts and bone remodeling," BoneKEy Reports, vol. 1, no. 4, 2012.

[42] G. A. Obando-Pereda, L. Fischer, and D. R. Stach-Machado, "Titanium and zirconia particle-induced pro-inflammatory gene expression in cultured macrophages and osteolysis, inflammatory hyperalgesia and edema in vivo," Life Sciences, vol. 97, no. 2, pp. 96-106, 2014.

[43] M. Di Rosa, M. Malaguarnera, F. Nicoletti, and L. Malaguarnera, "Vitamin D3: a helpful immuno-modulator," Immunology, vol. 134, no. 2, pp. 123-139, 2011.

[44] Q. A. Xu, Z. F. Li, P. Zhang, L. H. Cao, and M. W. Fan, "Effects of 1,25-dihydroxyvitamin $\mathrm{D}_{3}$ on macrophage cytokine secretion stimulated by Porphyromonas gingivalis," Japanese Journal of Infectious Diseases, vol. 69, no. 6, pp. 482-487, 2016.

[45] F. Mangano, C. Mortellaro, N. Mangano, and C. Mangano, "Is low serum vitamin D associated with early dental implant failure? A retrospective evaluation on 1625 implants placed in 822 
patients," Mediators of Inflammation, vol. 2016, Article ID 5319718, 7 pages, 2016.

[46] T. Fretwurst, S. Grunert, J. P. Woelber, K. Nelson, and W. Semper-Hogg, "Vitamin D deficiency in early implant failure: two case reports," International Journal of Implant Dentistry, vol. 2, no. 1, p. 24, 2016.

[47] T. Munhoz Pereira and F. Alvim-Pereira, "A complete physical mapping of the vitamin D receptor gene for dental implant loss: a pilot study," Clinical Oral Implants Research, vol. 30, no. 12, pp. 1165-1178, 2019.

[48] U. Schulze-Spate, T. Dietrich, C. Wu, K. Wang, H. Hasturk, and S. Dibart, "Systemic vitamin D supplementation and local bone formation after maxillary sinus augmentation - a randomized, double-blind, placebo-controlled clinical investigation," Clinical Oral Implants Research, vol. 27, no. 6, pp. 701-706, 2016.

[49] O. Salomo-Coll, "Topical applications of vitamin D on implant surface for bone-to-implant contact enhance: a pilot study in dogs part II," Clinical Oral Implants Research, vol. 27, no. 7, pp. 896-903, 2016.

[50] Y. J. Cho, S. J. Heo, J. Y. Koak, S. K. Kim, S. J. Lee, and J. H. Lee, "Promotion of osseointegration of anodized titanium implants with a $1 \alpha, 25$-dihydroxyvitamin D3 submicron particle coating," The International Journal of Oral \& Maxillofacial Implants, vol. 26, no. 6, pp. 1225-1232, 2011. 